\title{
Credit Constraints and the Cyclicality of R\&D Investment: Evidence from France
}

\section{Citation}

Aghion, Philippe, Philippe Askenazy, Nicolas Berman, Gilbert Cette, and Laurent Eymard. 2012. "Credit Constraints and the Cyclicality of R\&D Investment: Evidence from France." Journal of the European Economic Association 10, no. 5: 1001-1024.

\section{Published Version}

doi:10.1111/j.1542-4774.2012.01093.x

\section{Permanent link}

http://nrs.harvard.edu/urn-3:HUL.InstRepos:12490632

\section{Terms of Use}

This article was downloaded from Harvard University's DASH repository, and is made available under the terms and conditions applicable to Open Access Policy Articles, as set forth at http:// nrs.harvard.edu/urn-3:HUL.InstRepos:dash.current.terms-of-use\#OAP

\section{Share Your Story}

The Harvard community has made this article openly available.

Please share how this access benefits you. Submit a story.

\section{Accessibility}




\title{
Credit Constraints and the Cyclicality of R\&D Investment: Evidence from France
}

\author{
Philippe Aghion* Philippe Askenazy ${ }^{\dagger} \quad$ Nicolas Berman $^{\ddagger}$
}

Gilbert Cette $^{\S} \quad$ Laurent Eymard

\footnotetext{
${ }^{*}$ Corresponding author. Harvard University, Department of Economics, Littauer Center 309, Cambridge, MA. Phone: (617) 495-6675. Fax: (617) 495-4341. E-mail: paghion@fas.harvard.edu.

${ }^{\dagger}$ Paris School of Economics, Banque de France and IZA. E-mail: Philippe.Askenazy@ens.fr.

${ }^{\ddagger}$ PSE, University Paris I Panthéon-Sorbonne and Banque de France. E-mail: nicolas.berman@malix.univparis1.fr.

${ }^{\S}$ Banque de France and Aix-Marseille II University. E-mail: gilbert.cette@banque-france.fr.

`Banque de France. E-mail: laurent.eymard@ensae.org.
} 


\begin{abstract}
We use a French firm-level panel data set over the period 1993-2004 to analyze the relationship between credit constraints and firms' R\&D behavior over the business cycle. Our main results can be summarized as follows: (i) the share of R\&D investment over total investment is countercyclical without credit constraints, but it becomes more procyclical as firms face tighter credit constraints; (ii) the result is magnified for firms in sectors that depend more heavily upon external finance; (iii) in more credit constrained firms, R\&D investment share plummets during recessions but does not increase proportionally during upturns; (iv) average R\&D investment and productivity growth are more negatively correlated with sales volatility in more credit constrained firms.
\end{abstract}

JEL classification: E22, E32, O16, O30, O32.

Keywords: business cycles, R\&D, credit constraints, volatility. 


\section{Introduction}

A Schumpeterian view of business cycles and growth, is that recessions provide a cleansing mechanism for correcting organizational inefficiencies and for encouraging firms to reorganize, innovate or reallocate to new markets. The cleansing effect of recessions is also to eliminate those firms that are unable to reorganize or innovate. Schumpeter ${ }^{1}$ himself would summarize that view as follows; "[Recessions] are but temporary. They are means to reconstruct each time the economic system on a more efficient plan". This of course assumes that firms can always borrow enough funds to either reorganize their activities or move to new activities and markets. Without credit constraints, investment choices are indeed dictated by an opportunity-cost effect: namely, the opportunity cost of long-term innovative investments instead of short-term capital investments, is lower in recessions than in booms. Hence, the share of long-term investment in total investment should be countercyclical, whereas the share of short-term investment is procyclical (see Hall (1993), Gali and Hammour (1992), Aghion and Saint-Paul (1998), Bean (1990), Bloom (2007)).

However, as emphasized by Aghion et al. (2005), henceforth AABM, things become quite different when credit market imperfections prevent firms from innovating and reorganizing in recessions. In particular, suppose that firms can choose between short-run capital investment and long-term R\&D investment, that innovating requires that firms survive short-run liquidity shocks, and that to cover liquidity costs firms can rely only on their short-run earnings plus borrowing. Whenever the firm is hit by a bad (idiosyncratic or aggregate) shock, its current earnings are reduced, and therefore so is the firms' ability to borrow in order to innovate. This in turn implies that a negative shock should hit R\&D investments and innovation more in firms that are more credit constrained. In other words, R\&D investments should be expected to be

\footnotetext{
${ }^{1}$ See Schumpeter (1942).
} 
more procyclical in firms facing tighter credit constraints.

In this paper, we test this prediction using a French firm-level panel data set that contains information both, on the extent of credit constraints at the firm level each year, and on R\&D investments by the firm, relative to total investment. The firm-level database we use has been collected by the Banque de France. The sample includes about 13,000 firms (all of them having at least one time a positive $R \& D$ investment) and covers the period 1993-2004. The database contains an important number of small and medium firms that are particularly prone to be hit by credit constraints, and are thus especially relevant for the study of the above-mentioned mechanisms. The most interesting feature of this dataset is that it contains information on credit constraints at the firm level. More specifically, firms that fail to repay their trade creditors are identified on a list to which banks have access. Our first stage regression shows that being notified on that list under the heading "incident de paiement", is negatively and significantly correlated with a firm's access to future loans.

Once equipped with this firm-level information on credit access, we regress firm R\&D over total investment on firm sales and its interaction with credit constraints. Our main results from second stage regressions can be summarized as follows: (i) the share of R\&D investment over total investment is countercyclical without credit constraints, and it becomes more procyclical as firms face tighter credit constrained; (iii) this effect is only observed during downturns: namely, in presence of credit constraints, $R \& D$ investment share plummets during recessions but it does not increase proportionally during upturns; (iv) the level of R\&D investment is lower in more credit constrained firms whatever the firm's position within the business cycle but it decreases more during recessions. Therefore, credit constraints, by preventing the R\&D share from being countercyclical, may amplify the business cycle, increase productivity growth volatility and decrease average productivity growth. 
This paper relates to a broader literature on cycles, innovation and growth. The theoretical papers that are most closely related to our approach in this paper, are Hall (1991), Gali and Hammour (1992), Caballero and Hammour (1994), Aghion and Saint-Paul (1998), Francois and Lloyd-Ellis (2003), Comin and Gertler (2006), Barlevy (2004), and Barlevy (2007). All these papers take a Schumpeterian approach to the relationship between growth and cycles, however they do not emphasize credit constraints. The empirical literature on the subject starts with Ramey and Ramey (1995) who provide cross-country evidence of a negative relationship between volatility and growth. More closely related to the analysis in this paper is AABM. Based on cross-country panel data over the period 1960-2000, AABM show that structural investment (another proxy for growth-enhancing investment) is more procyclical in countries with lower ratios of credit to GDP, and that the correlation between macroeconomic volatility (measured as in Ramey and Ramey (1995) by the variance of growth rate) and average growth, is more negative the lower financial development. However, unlike in this paper, the data in AABM do not include R\&D investments, and moreover credit constraints are not measured at the firm level. Prior evidence on R\&D investments over the cycle, is provided by Griliches (1990), Comin and Gertler (2006), and Barlevy (2007), although not in relation to firms' credit constraints $^{2}$.

The paper is organized as follows. Section 2 presents a simple model to derive our main predictions. Section 3 presents the data and the measurement variables. Section 4 presents the first stage analysis, where we regress credit access on firms' past credit records. Section 5 presents the second stage results. Section 6 discusses the robustness of our results and their implications for productivity growth and volatility, and it concludes.

\footnotetext{
${ }^{2}$ Barlevy (2007) finds no evidence of current cash flows affecting how firms'current R\&D investments respond to the business cycle. However, in Barlevy's own estimations, lagged cash flows turn out to significantly affect how current R\&D investment reacts to the firm's current position in the business cycle.
} 


\section{Model}

\section{Basic environment}

There is a continuum of overlapping-generations of two period lived entrepreneurs. Entrepreneurs are risk-neutral and maximize intertemporal wealth.

An entrepreneur born at date $t$ faces a sales shock $a_{t}$ at time $t$ and $a_{t+1}$ at time $t+1$, where

$$
a_{t} \in\{\underline{a}, \bar{a}\}
$$

and

$$
\begin{aligned}
p & =\operatorname{Pr}\left(a_{t+1}=\bar{a} / a_{t}=\bar{a}\right) \\
& =\operatorname{Pr}\left(a_{t+1}=\underline{a} / a_{t}=\underline{a}\right)
\end{aligned}
$$

is strictly less than one but greater than $1 / 2$ so that there is some persistence to a sales shock over time.

At the beginning of her first period, an entrepreneur born at date $t$ decides about: (i) shortrun capital investment $k_{t}$, which yields short run profit $a_{t} k_{t}$ at cost $\frac{1}{2} d k_{t}^{2}$ at the end of the first period, and; (ii) long-term $\mathrm{R} \& \mathrm{D}$ investment $z_{t}$, which yields an innovation value $v_{t+1}$ equal to the expected productivity $E\left(a_{t+1} / a_{t}\right)$ in period $(t+1)$ with probability $z_{t}$ in the second period, at cost $\frac{1}{2} c z_{t}^{2}$. Credit market imperfections may prevent a firm with short-run profit flow $a_{t} k_{t}$ from investing more than $\mu a_{t} k_{t}$ in $\mathrm{R} \& \mathrm{D}$, where $\mu \geq 1$ measures the extent to which the firm can borrow using its first period return as collateral. 


\section{Profit maximization and optimal investments}

Consider first the benchmark case where the entrepreneur is not credit constrained. Then she will choose $k$ and $z$ to

$$
\max _{k, z}\left\{a_{t} k+E\left(a_{t+1} / a_{t}\right) z-\frac{1}{2} d k^{2}-\frac{1}{2} c z^{2}\right\}
$$

which yields

$$
\begin{aligned}
d k & =a_{t} ; \\
c z & =E\left(a_{t+1} / a_{t}\right)=p a_{t}+(1-p) a_{-t},
\end{aligned}
$$

where

$$
a_{-t} \neq a_{t}
$$

In particular, given that $p<1$, the ratio

$$
\frac{z}{k}=\frac{d}{c} \frac{E\left(a_{t+1} / a_{t}\right)}{a_{t}}=\frac{d}{c}\left[p+(1-p) \frac{a_{-t}}{a_{t}}\right]
$$

is countercyclical, that is, lower when sales are high with $a_{t}=\bar{a}$ than when sales are low with $a_{t}=\underline{a}$. This is the opportunity cost effect already mentioned in the introduction.

Now, consider the case where the entrepreneur is credit-constrained. Then she will choose $k$ and $z$ to

$$
\begin{aligned}
& \max _{k, z}\left\{a_{t} k+E\left(a_{t+1} / a_{t}\right) z-\frac{1}{2} d k^{2}-\frac{1}{2} c z^{2}\right\} \\
& \text { s.t. } \quad z \leq \mu k a_{t} .
\end{aligned}
$$


The credit-constraint is binding whenever the equilibrium R\&D level in the absence of credit constraint, is higher than $\mu k a_{t}$ in equilibrium, that is, whenever:

$$
\frac{E\left(a_{t+1} / a_{t}\right)}{c}>\mu \frac{\left(a_{t}\right)^{2}}{d}
$$

This latter condition, which can be reexpressed as

$$
\frac{1}{c}\left[p+(1-p) \frac{a_{-t}}{a_{t}}\right]>\mu \frac{a_{t}}{d}
$$

is more likely to be satisfied when the firms faces a low sales shock (with $a_{t}=\underline{a}$ and $a_{-t}=\bar{a}$ ) than when it faces a high sales shock (with $a_{t}=\bar{a}$ and $a_{-t}=\underline{a}$ ).

Suppose first that the credit constraint binds only when sales are low. Then the ratio of R\&D over capital investment $\frac{z}{k}$ is necessarily procyclical. To see this, note that: (i) when $a_{t}=\bar{a}$, this ratio is unconstrained and thus from (3) it is equal to:

$$
\left(\frac{z}{k}\right)^{h i g h a}=\frac{d}{c}\left[p+(1-p) \frac{a}{\bar{a}}\right]
$$

(ii) when $a_{t}=\underline{a}$ the credit constraint is binding so that the $\mathrm{R} \& \mathrm{D} /$ capital ratio is equal to

$$
\left(\frac{z}{k}\right)^{l o w a}=\mu \underline{a}
$$

(iii) our assumption that (4) is satisfied for $a_{t}=\underline{a}$, which immediately implies that

$$
\left(\frac{z}{k}\right)^{l o w a}<\left(\frac{z}{k}\right)^{h i g h a}
$$

Another predictions in this case is that a lower $\mu$ reduces $\left(\frac{z}{k}\right)^{\text {lowa }}$ without affecting $\left(\frac{z}{k}\right)^{\text {higha }}$. 
Thus, lowering $\mu$ will result in a lower equilibrium $R \& D$ investment reduced in a low sales shock, whereas the R\&D investment is unchanged in a high sales shock.

Overall, the RED/capital ratio will be more procyclical in a firm facing tighter credit constraints, and that this firm will also invest relatively less in REDD on average over time. These predictions will be validated by our empirical analysis in the next sections.

Now, suppose that condition (4) is always binding. Then the equilibrium $R \& D /$ capital ratio remains procyclical, with

$$
\left(\frac{z}{k}\right)^{l o w a}=\mu \underline{a}<\left(\frac{z}{k}\right)^{h i g h a}=\mu \bar{a} .
$$

However, in this case, a lower $\mu$ will reduce the $\mathrm{R} \& \mathrm{D} /$ capital ratio $\frac{z}{k}$ more when the firm faces high sales (when $a_{t}=\bar{a}$ ) than when it faces low sales $\left(a_{t}=\underline{a}\right)$ since

$$
\frac{d}{d \mu}\left[\left(\frac{z}{k}\right)^{h i g h a}-\left(\frac{z}{k}\right)^{l o w a}\right]=\bar{a}-\underline{a}>0
$$

This case is not the most plausible, as we can expect firms to be less credit-constrained in high than in low-sales states. And indeed our empirical analysis will not support this latter prediction that tightening credit constraints should reduce the $R \& D$ share of investment by more in upturns than in downturns.

To complete our analysis of the model, we can derive the equilibrium R\&D investment under high and low current sales respectively. If the credit constraint does not bind, then from (2) we have:

$$
z=\frac{E\left(a_{t+1} / a_{t}\right)}{c}
$$


And if it binds one can show that ${ }^{3}$ :

$$
z=\frac{1}{d+c\left(\mu a_{t}\right)^{2}} \mu\left(a_{t}\right)^{2}\left[1+\mu E\left(a_{t+1} / a_{t}\right)\right]
$$

It then follows that R\&D is procyclical when the credit constraint binds in the low sales state. This is obvious when the firm is also constrained in the high sales state, as:

$$
\frac{\bar{a}^{2}}{d+c(\mu \bar{a})^{2}}>\frac{\underline{a}^{2}}{d+c(\mu \underline{a})^{2}}
$$

and

$$
[1+\mu(p \underline{a}+(1-p) \bar{a})]<[1+\mu(p \bar{a}+(1-p) \underline{a})]
$$

when $p>1 / 2$. It is a fortiori true when the firm is constrained in the low sales state only since the credit constraint affects the R\&D investment primarily.

\footnotetext{
${ }^{3}$ To see this, note that when the credit constraint binds, we have

$$
z=\mu k a_{t}
$$

so that the optimal capital investment $k$ solves:

$$
\max _{k}\left\{a_{t} k+E\left(a_{t+1} / a_{t}\right) \mu k a_{t}-\frac{1}{2} d k^{2}-\frac{1}{2} c\left(\mu k a_{t}\right)^{2}\right\} .
$$
}

From first order condition we get:

$$
k=\frac{1}{d+c\left(\mu a_{t}\right)^{2}} a_{t}\left[1+\mu E\left(a_{t+1} / a_{t}\right)\right]
$$

and therefore

$$
\begin{aligned}
z & =\mu k a_{t} \\
& =\frac{\mu}{d+c\left(\mu a_{t}\right)^{2}}\left(a_{t}\right)^{2}\left[1+\mu E\left(a_{t+1} / a_{t}\right)\right] .
\end{aligned}
$$




\section{Main theoretical predictions}

The main predictions that emerge from our analysis in this section can be summarized as follows:

1. A firm's (relative) R\&D investment is more procyclical (in the sense that it reacts more positively to the firm's current sales), the more credit-constrained the firm is.

2. Tighter credit constraints interact with sales in an asymmetric fashion over the business cycle. In particular, starting from a situation where credit constraints are more binding in downturns, a tightening of credit-constraints or an increase in the volatility of sales, reduce the firm's R\&D investment more in a downturn than it might increase it in an upturn. It thus reduces the firm's average R\&D investment.

In the remaining part of the paper we take these predictions to French firm-level panel data.

\section{Data}

Our empirical analysis merges two different French-firm-level datasets: FiBen and the payment incident dataset, which we now describe in more details.

\section{The FiBEn database}

Our core data comes from FiBEn, a large French-firm-level database constructed by the Banque de France. FiBEn is based on fiscal documents, including balance sheet and P\&L statement, and thus contains detailed information on both, flow and stock accounting variables. A subsample of FiBEn, called Centrale des Bilans, is available for a lower number of firms and includes 
additional information directly collected by the Banque de France. This additional data will allow us to perform additional consistency and accuracy tests.

The FiBen database includes all French firms which sales at least equal to 75,000 euros or with credit outstanding of at least 38,000 euros; annual accounting data are then available for about 200,000 firms. In 2004, FiBEn covered $80 \%$ of the firms with 20 to 500 employees, and $98 \%$ of those employing more than 500 employees $^{4}$.

We then restrict our sample by looking only at firms that have at least one year a positive R\&D investment; our sample is unbalanced and includes about 13,000 firms over the period 1993-2004. A same firm appears in our database during a seven year period on average.

[Table 1 about here]

[Table 2 about here]

Tables 1 and 2 present summary statistics for our key variables, including the R\&D share of investment, and the measure of credit constraint we use in the empirical analysis; this measure, which is referred to as "payment incident", will be described and analyzed in details in the two next subsections.

Our final sample includes an important number of small and medium firms ${ }^{5}$, that are particularly prone to be hit by credit constraints.

\footnotetext{
${ }^{4}$ More than $50 \%$ of the firms in FiBEn have less than 20 employees. However, these firms are underrepresented in FiBEn since their sales rarely exceed the required amount.

${ }^{5}$ The median size is of around 30 employees per firm.
} 


\section{R\&D variable}

Among the variables for which FiBEn data are available, we choose to concentrate on R\&D investment rather than R\&D expenditures as a proxy for long-term, productivity-enhancing investment. $R \& D$ investments are a fraction of $R \& D$ expenditures that the firms are allowed to capitalize. The reason for relying on this measure is twofold. First, it makes the ratio of R\&D investment over total investment, which is central in our study, more homogenous. Second, R\&D investment is much more volatile than R\&D expenditures, since the latter include in an important way researchers wages that are more stable along the business cycle. Note that the accounting behavior of firms should not been affected by changes in the fiscal environment: the R\&D fiscal rules has not been significantly altered during the studied period ${ }^{6}$. Using R\&D investment, we check that the sectoral R\&D intensity is as expected (that is the lowest for agriculture and the highest for services to businesses that include business software developments).

We also check whether our variable has a positive long-term effect on TFP growth. Table 3 shows a clear positive correlation. An increase of the ratio $R \& D$ investment over value added is associated with a significant rise of future TFP growth. The ratio R\&D over total investment also has a positive and significant impact.

[Table 3 about here]

\section{Payment incidents}

Direct firm-level information on credit constraints is not available in France. However, we could derive an indirect measure of credit constraints, as follows. Since its introduction in 1992, all French banks have a legal obligation to report any previous default on trade creditors to the

\footnotetext{
${ }^{6}$ The main reforms have been implemented during the fiscal years 1990 and in 2005.
} 
"Système Interbancaire de Télécompensation" within four business days. These defaults on trade credit are called payment incidents (henceforth PI). The Banque de France aggregates this information and makes it available to all commercial banks through a weekly paper or an electronic report automatically sent to all bank agencies. Also, since 1992, through a specific commercial network system, banks can immediately access these reports covering the last 12 months; access is through internet since 2000. The complete longitudinal dataset is available for research only at the Bank of France.

Banks are thus supposed to adapt their credit supply to this information, in particular they typically reduce future lending to defaulting firms. Our proxy for credit constraints is a binary variable equal to 1 when the firm has experienced at least one payment incident during the previous year, and to zero otherwise. This variable is easy to interpret and weakly correlated to our other key variables (see Table 13 in appendix). About 7\% of firms experience each year at least one payment incident, and about one third of firms in our sample has experienced at least one payment incident over the overall period. All sectors are concerned by payment incidents, especially manufacturing motor vehicles that includes small and medium subcontractors facing the strong cyclicality of this industry. Conversely, real estate firms are less affected by the business cycle and experience fewer payment incidents (table 2).

Our descriptive statistics table (1) shows that credit constrained firms (here defined as the firms that have experienced at least 1 payment incident during the period) display a lower ratio of R\&D investment over total investments, and a higher volatility (measured by the standard deviation) of sales. This is consistent with the theoretical predictions: if credit constraints are in action, the share of productivity-enhancing investment over total investment turns less countercyclical (or even procyclical). Credit constraints thus prevent R\&D from having a smoothing effect on productivity and magnifies the business cycle - sales are more volatile. We 
confirm these stylized facts in the next sections.

\section{First stage: Payment Incidents as a proxy for credit}

\section{constraints}

In this section we investigate the effect of experiencing a payment incident (PI) on future bank loans. More precisely, we study the impact of having experienced at least one PI during the two previous years $(t-1$ and $t-2)$ both on the probability to contract a new bank loan, and on the amount of this loan. We estimate the following specification:

$$
B k L_{i, t}=\alpha_{1} P I_{i, t-1}+\alpha_{2} P I_{i, t-2}+\beta_{j} X_{i, t-1}+\mu_{t}+\rho_{i}+\epsilon_{i, t}
$$

where $B k L_{i, t} \geq 0$ represents the amount of new bank loans contracted by firm $i$ during year t, $P I_{i, t-1}$ is a binary variable equal to 1 whenever firm $i$ had a payment incident during year $t-1$, and $X_{i, t-1}$ is a set of controls that includes various determinants of bank loans supply. In particular, we control for firm size (number of employees) and its squared value, for the firm's cash-flow, and for collateral and the firm's dependence upon bank finance (banking debt over total debt $)^{7}$. All these variables are lagged.

We expect the supply of bank loans to be higher for firms with higher cash flow and collateral. Size may have a non-linear effect - i.e. a lower positive effect on credit supply at higher levels. Finally, we expect the estimated coefficients on the PI variable to be negative - banks are

\footnotetext{
${ }^{7} \mathrm{~A}$ more detailed description of the computation of these different variables is provided in the Appendix Table 12.
} 
supposed to reduce their credit supply to defaulting firms.

We also include a full set of year dummies to account for time specific effects, and estimate the equation with firms' fixed effects. Alternatively, we use a GMM procedure; we also assess separately the impact of having experienced a payment incident in the past, on both, the access to new bank loans (by using a Logit estimation) and on the amount of this loan (by using a left-censored, Tobit estimation). Finally, we replace the dependent variable "new bank loans" by the share of long term loans over total loans. The idea here is that credit constrained firms have relatively more short term loans as banks are more reluctant to give them long terms ones. We thus expect the coefficient on PI to be negative in this latter estimation.

Our specification only takes into account supply factors in explaining firms' new bank loans'. However, our regressors may be correlated with factors which affect firms' demand for new loans. In particular, the demand for credit should be positively correlated with firms' investment demand, which itself should be positively correlated with current sales. To partly capture this demand effect, we introduce lagged sales variation, and the lag of the share of R\&D investment over value added as additional controls.

[Table 4 about here]

Results are shown in Table 4. The estimated coefficients on control variables have the expected sign: a larger cash flow, size and collateral are all positively correlated with banks credit supply (columns (a) to (d)). Results are qualitatively unchanged when controlling for past sales variations (columns (i) and (j)). Having experienced a payment incident during the previous year has a negative and significant impact, both on the probability to contract a new loan (logit estimation, column (l)) and on the size of the loan (within estimations). In the last two columns we decompose the marginal effects computed from a left-censored tobit 
estimation of the previous specification in two subcomponents: namely, the marginal effect on the probability to contract a new loan and the effect on the size of the loan. Having experienced a payment incident has more negative impact both on the size of the loan than on the probability to contract a new loan. We also find that having experienced a payment incident two years before does not have any impact on credit supply ${ }^{8}$. One potential explanation for this latter finding is that the electronic service provided by the Bank of France gives commercial banks access to only the past year PI. Note that the introduction of the convivial internet access in 2000 does not seem to have modified the correlation between PI and credit supply between before and after 2000 (columns (f) and (g)). Finally, our results exhibit a negative correlation between PI and the share of long-term debt in total debt - an especially important fact since we will study in the next part the effect of credit constraints on the share of long-run investment.

These findings are consistent with the idea of a significant impact of payment incidents on credit supply. We shall build on these results in our second-stage analysis, in which we use the binary variable equal to 1 whenever the firm has experienced at least one PI in year $t-1$, as our proxy for credit constraint in year $t$.

As we explain in more details in the next section, this measure of credit constraint is not immune from potential endogeneity problems. In particular, both the composition of investment and the fact of having experienced a payment incident, may result from the existence of omitted variables. For example the firm may decide that a given activity is no longer worth pursuing, and as a result reduce both, its $\mathrm{R} \& \mathrm{D}$ investment and also its diligence vis-a-vis trade creditors in that activity. To deal with the endogeneity problem and further confirm the relevance of payment incidents as a proxy for credit constraints, we use the Rajan and Zingales (1998)'s

\footnotetext{
${ }^{8}$ We also tried to determine whether the number of payment incidents or the extent of the unpaid trade credits play a role; we find that payment incidents have nearly the same effects on R\&D share over the business cycle no matter the number or magnitude of incidents.
} 
industry-level measure of financial external dependence ${ }^{9}$. More precisely, we shall run our second-stage estimations on two different sub-samples, respectively containing highly and lowly dependent sectors. We explain our methodology in more details in the next section.

\section{Second stage: credit constraints and the cyclicality of}

\section{R\&D investment}

In this section we use our PI measure of credit constraints to test our main theoretical predictions. In particular we will show that: (1) the R\&D / investment ratio is more procyclical for firms facing tighter credit constraints; (2) this procyclicality effect tends to be asymmetric: it operates mainly during low sales states. The next section will discuss robustness checks and implications of our results, in particular for the effect of volatility on the level of R\&D and on average productivity growth in credit-constrained firms.

\section{Proposition 1: Cyclicality of the R\&D share and credit constraints}

\subsection{Specification}

We test our first proposition by estimating the following specification:

$$
\begin{gathered}
\frac{R D_{i, t}}{I_{i, t}+R D_{i, t}}=\alpha_{0}+\beta_{1} \Delta s_{i, t}+\beta_{2} \Delta s_{i, t-1}+\beta_{3} \Delta s_{i t-2}+\theta P I_{i, t-1}+ \\
\gamma_{1} \Delta s_{i, t} * P I_{i, t-1}+\gamma_{2} \Delta s_{i, t-1} * P I_{i, t-1}+\gamma_{3} \Delta s_{i, t-2} * P I_{i, t-1}+\mu_{t}+\nu_{i}+\varepsilon_{i t}
\end{gathered}
$$

\footnotetext{
${ }^{9}$ See Rajan and Zingales (1998). The RZ indicator measures the extent to which the corresponding sector in the US is more or less dependent upon external finance.
} 
where $R D_{i t}$ represents $\mathrm{R} \& \mathrm{D}$ investment (used as a proxy for long-term, productivity enhancing investment), $I_{i, t}+R D_{i, t}$ total investment (physical plus R\&D investment), $P I_{i, t-1}$ the payment incident dummy (used as a proxy for credit constraints), and $\Delta s_{i t}$ the variation in sales ${ }^{10}$ of firm i during year $t$. We control for time fixed effects $\mu_{t}{ }^{11}$, and for firms fixed effects.

We thus analyze the interacted impact of sales cycles and credit constraints on the composition of investment. Based on our theoretical analysis, we expect the share of R\&D investment to be countercyclical in the absence of credit constraints; we thus expect $\beta_{1}<0$ and $\sum \beta_{i}<0$. However, credit constraints are supposed to reverse the cyclicality of investment composition: they should lead to a more procyclical long-run investment $\left(\gamma_{1}>0, \sum \gamma_{i}>0\right)$. Finally, by themselves credit constraints have an uncertain effect on investment composition. For example, a firm may reduce its demand for short-run investment more when it is credit constrained; but long-run investment should also be negatively affected by credit supply. Thus, we do not expect a particular sign or significance on $\theta$.

As mentioned before, we estimate the equation with firm fixed effects. The results are almost unchanged when using a Random effects / GLS methodology with sector and size dummies ${ }^{12}$. Moreover, taking into account the important share of zero-values in our R\&D variable by estimating the previous specification using a left-censored Tobit does not change the results qualitatively either.

However, a potential bias arises when using the within estimator, since some of the inde-

\footnotetext{
${ }^{10}$ Defined as: $\log \left(\right.$ Sales $\left._{t}\right)-\log \left(\right.$ Sales $\left._{t-1}\right)$.

${ }^{11}$ We also included year $\times$ sector dummies to account for sectoral shocks such as privatization. Results were unaffected.

${ }^{12}$ The inclusion of these controls in a within estimation does not add much since sectors and size specific effects are already captured by the firms' fixed effects.
} 
pendent variables - in particular $\Delta s_{i, t}$ - may be simultaneously determined with the dependant variable. More specifically, it seems clearly unlikely that investment and sales would not be simultaneous to some extent. A solution to this bias is to use an instrumental variable (IV) methodology, where the instruments are an appropriated set of lagged values of the variables. This in turn argues in favor of using the GMM method, at least to control for the robustness of our results. We thus replicate each basic result using the Arellano and Bond (1995) estimator. The validity of the instruments is verified by the classical Sargan test for over-identifying restrictions.

\section{$1.2 \quad$ Results}

Columns a, b and c in Table 5 report the within estimations of the potential impact of sales changes on the composition of investment. These estimations include current sales shocks and up to two-period lagged shocks.

These first results show a countercyclicality of the share of R\&D in the investment spending. A 10 percent change in current sales induces a modification in the opposite direction of the share of R\&D of 0,2 percentage point the same year, and also the next year, and still half of this effect two years after. But the correlation vanishes for older shocks (regressions not reported). The magnitude of the current impact of this 10 percent change in current sales is quite important: about $4 \%$ of the R\&D average share. Finally, these results are robust to the use of GMM estimators.

[Table 5 about here]

Introducing PI as an additional explanatory variable does not also alter the countercyclicality of the share of R\&D in the investment spending. On its own, PI shows no significant 
impact on the R\&D share in the within estimation, however using the GMM procedure makes the payment incident coefficient become significant and negative. This suggests that R\&D investment tends to be more negatively affected than physical investment by the occurrence of payment incidents. Intuitively, firms with credit constraints tend to favor short-term investments relatively to long-term ones. Facing at least one payment incident the previous year may be associated with a large drop of the share of R\&D of 0,5 percentage point, about $10 \%$ of the R\&D average share.

Now, when we interact PI with our sales shock variables, we obtain the desired results: consistent with theoretical predictions, the share of R\&D investment turns less countercyclical in presence of credit constraints (Table 5, columns d, e and f).

To deal with potential endogeneity problems linked to the co-determination of sales and investment, we first run GMM estimations (GMM, Table 5). This does not affect the results on the R\&D share cyclicality - on the contrary, the interaction term between sales variations and payment incident becomes significant in $t-1$. However, the Sargan test rejects the validity of our instruments, in line with previous work emphasizing the weakness of GMM instruments in this kind of estimations ${ }^{13}$.

\subsection{Robustness}

As already mentioned in the previous section, another source of endogeneity lies in the possibility that both, a firm's investment structure and whether it is subject to a payment incident, may hinge on some omitted variable. Note that the omitted variables have to be firm-year specific (if not, it is captured by year or firm fixed effects), and to co-determine PI in year $t-1$ and the R\&D share of investment in year $t$, without affecting the $R \& D$ share at $t-1$ in the

\footnotetext{
${ }^{13}$ See for example Mulkay et al. (2001).
} 
same way as it affects the $R \& D$ share at $t$ (since the inclusion of a lagged term of the dependant variable does not modify the results). These variables cannot be sector-year specific since the inclusion of sector-year dummies leaves the results unchanged.

To deal with this potential endogeneity problem, we use the sectoral financial dependence indicator of Rajan and Zingales (1998). More precisely, we run the last set of estimations on two different sub-samples, respectively consisting of sectors with analogs in the US that are more (above median) and less (below median) financially dependent. Our idea is here twofold. First, there is a priori no reason for this endogeneity bias to be differently distributed across sectors with different levels of external dependence, that is, for the omitted variable to affect $\mathrm{PI}(\mathrm{t}-1)$ and the structure of investment in year $\mathrm{t}$ (with the above restrictions) only in sectors that are more dependent upon external finance. Second, the previous results should be exacerbated in more financially dependent sectors. Hence, getting more significant results on the financially dependent sub-sample, would suggest both that the endogeneity bias is weak and that payment incident is indeed a good proxy for firm-level credit constraints. We then repeat the same exercise, but dividing up our sample according to firms' collateral. Thus, we run separated estimations for firms with higher (above median) and lower (below median) collateral and expect stronger correlations in the latter sub-sample. Collateral is computed as the sum of fixed and tangible assets.

[Table 6 about here]

Results provided in table 6 show that the share of R\&D investment becomes more procyclical in presence of credit constraint only for firms in sectors that are more dependent upon external finance or in firms with lower collateral (columns (b) and (c)). Estimated coefficients are insignificant for firms the other sub-samples. This in turn suggests a causal effect of credit 
constraints on the procyclicality of R\&D investments.

\section{Proposition 2: Asymmetry between positive and negative shocks}

\subsection{Specification}

The interactions terms in the previous tables need to be interpreted with precaution: their positive signs can mean either that credit constraints prevent firms from increasing their R\&D share in downturns, or that firms increase more this share during upturns periods when they are financially constrained.

In this section, we disentangle the up- and downturns effects and show that the effect of credit constraints on the R\&D share depends upon the firm's position within its business cycle. Intuitively, one expects this effect to be stronger during downturns as credit constraints are more likely to be binding in that case. More specifically, we decompose the sales variation variable in two components: downturns (first quartile of sales variations) and upturns (last quartile). We implicitly assume that a large negative shock leads to the equivalent of our $\underline{a}$ whereas a large positive shock leads to the equivalent of our $\bar{a}$.

We expect credit constraints to prevent firms from increasing their R\&D share mainly during downturns, thus it is the interaction terms between this variable and payments incidents that should be most positive and significant. The specification becomes:

$$
\begin{aligned}
& \frac{R D_{i, t}}{I_{i, t}+R D_{i, t}}=\alpha_{0}+\sum_{j=0}^{2}\left(\alpha_{j} \Delta s_{i, t-j}^{H}+\gamma_{j} \Delta s_{i, t-j}^{L}\right)+\alpha_{4} P I_{i, t-1}+ \\
& \sum_{j=0}^{2}\left(\theta_{j} \Delta s_{i, t-j}^{H} * P I_{i, t-1}+\lambda_{j} \Delta s_{i, t-j}^{L} * P I_{i, t-1}\right)+\mu_{t}+\nu_{i}+\varepsilon_{i t}
\end{aligned}
$$


where $\Delta s_{i, t}^{H}$ equals sales variations if the firm is above its mean value for this variable, and to 0 otherwise; $\Delta s_{i, t}^{L}$ equals sales variations if the firm is below its mean, 0 otherwise. We also use another decomposition of sales shocks, by sector: in this case, $\Delta s_{i, t}^{H}$ equals sales variations if the firm is above the third quartile (computed by sector) of this variable and zero otherwise; similarly $\Delta s_{i, t}^{L}$ equals sales variations if the firm below the first quartile, and zero otherwise ${ }^{14}$.

Our contention is that credit constraints should play a more important role during recessions $\left(\lambda_{j}>0, \lambda_{j}>\theta_{j}\right)$

\section{$2.2 \quad$ Results}

[Table 7 about here]

Results are provided in table 7. In particular we see that the interaction term between sales variation and PI is significant only for lower shocks. Furthermore, the share of R\&D investment turns procyclical $^{15}$ for the lower shocks in case of a PI while it is countercyclical when no PI occurs. A 10 percent drop in current sales in a firm experiencing a PI in the previous year, induces a significant reduction of the share of $R \& D$ in total investment of about 0.25 point (5\%), but for a firm that has not experienced PI this share falls down to 3\%. Finally, whether firms are subject to PI or not, the share of R\&D in total investment becomes countercyclical for large positive sales shocks. This is consistent with the view that firms escape their credit constraints thanks to upward positions in their business cycle. These results are robust to the

\footnotetext{
${ }^{14}$ We also tried with alternative decompositions, based on quartiles computed by year, of sector-year. The results were qualitatively unchanged.

${ }^{15}$ This procyclicality is confirmed by a Wald test, showing that the coefficient on $\Delta s_{t}$ is significantly lower than the coefficient on $\Delta s_{t} * P I(t-1)$.
} 
alternative decomposition of the shocks ${ }^{16}$. Note also that the uninteracted effect of PI is not affected by the decomposition.

\section{Shock and cyclical position of the firm}

One objection to the previous estimation is the implicit assumption that the size of shocks determines the position of the firm within its business cycle. However, even if firms are in the low (resp. high) part of their business cycle (resp. high) they may experience large negative (resp. positive) shocks.

To handle this caveat, we divide our sample according to the initial position of firms. We assume that a firm is already lying on the upward (resp. downward) part of its cycle if the real sales per employee are above (resp. below) its median.

- When a firm lies initially in the upward part of its cycle at time $t-1$, we expect: (i) that the effect of a high sales shock alone should be either negative (the share of R\&D investment becomes more countercyclical as the firm moves further up) or insignificant (as the share of $\mathrm{R} \& \mathrm{D}$ investment is low from the start); (ii) that the effect of a payment incident on the $R \& D$ share is insignificant as the credit constraint is essentially not binding; (iii) that a low sales shock should significantly increase the share of R\&D; (iv) finally, that the interaction effect between PI and a (small) sales shock should not be significant.

- When a firm lies initially in the downward part of its cycle at $t-1$, the interaction between PI and a positive sales shock should become positive and significant.

[Table 8 about here]

\footnotetext{
${ }^{16}$ We also obtain similar qualitative results using GMM estimates (not presented, available on request).
} 
Results in Table 8 are consistent with these predictions and our previous estimations. Whatever the initial position of the firm, the correlation between a sales shock and the R\&D share is, as expected, non positive for firms without PI and non negative for firms affected by a PI. In addition, if the initial position of the firm is high, the coefficients are significantly different from zero when the sales shock is adverse. Alternatively, if the initial position of the firm is low, the coefficients are significantly different from zero when the sales shock is positive.

\section{Discussion and conclusions}

In this section we discuss some extensions and implications of our analysis. First, we argue that our main results carry over when we move from R\&D share of investment to R\&D levels: in other words, the higher procyclicality of the R\&D share in a more credit-constrained firm, is not primarily driven by a variation in its physical investment. Second, we move from R\&D share to firm level productivity growth and analyze how this latter variable responds to sales volatility interacted with firm-level credit constraints.

\section{From R\&D share to R\&D level}

As total investments are not constant over the firm's business cycle, our previous results do not provide direct information on how the average level of $\mathrm{R} \& \mathrm{D}$ investment is affected by credit constraints. For example, a procyclical $R \& D$ share would be consistent with the level of $R \& D$ either increasing or decreasing, if it turned out that the amount of physical invesment increases sufficiently during slumps.

To check that the reaction of the R\&D share to sales volatility, indeed reflects an adjustment of the R\&D level, we use the following specification: 


$$
\frac{I_{i, t}}{K_{i, t-1}}=\alpha_{0}+\eta_{1} \frac{I_{i, t-1}}{K_{i, t-2}}+\xi_{1} \Delta s_{i, t}+\xi_{2} \Delta s_{i, t-1}+\alpha_{1} P I_{i, t-1}+\beta_{1} \Delta s_{i, t} * P I_{i, t-1}+\beta_{2} \Delta s_{i, t-1} * P I_{i, t-1}+\mu_{t}+\nu_{i}+\varepsilon_{i t}
$$

where $I_{i, t}$ is physical investment, $K_{i, t}$ denotes capital stock, and $\Delta s_{i, t}$ is the variation in sales of firm $i$ during year $t$. The dependent variable is the accumulation rate of physical capital. How the level of $R \& D$ responds to sales shocks and their interaction with PI, is directly deductible from these results. We estimate this equation with firms and times fixed effects ${ }^{17}$.

We expect physical investment to be procyclical $\left(\xi_{1}, \xi_{2}>0\right)$ and negatively affected by credit constraints $\left(\alpha_{1}<0\right)$. The signs of $\beta_{1}$ and $\beta_{2}$ provide direct information on the cyclical variation of both physical investment and $R \& D$ in response to sales variations. If, unlike for R\&D investment, physical investment turns out to be affected by credit constraints in the same way whatever the firm's position within the business cycle $\left(\beta_{1}, \beta_{2}<0\right)$ - then the results in the previous section on the procyclicality of $R \& D$ share in more credit constrained firms, must carry over to the adjustment of R\&D levels over the firm's business cycle.

[Table 9 about here]

Our results are in line with these predictions. Table 9 shows that the level of physical investment is procyclical, and negatively affected by credit constraints no matter the firm's

\footnotetext{
${ }^{17} \mathrm{We}$ also have estimated the effect of PI and its interaction with $\Delta s_{t}$ using structural investment equations based on Mulkay et al. (2001). The results, available upon request, were qualitatively unchanged.
} 
location within the business cycle. More importantly, physical investments are uniformly affected by credit constraint over the business cycle. This, together with our previous findings, makes it clear that: (a) the average level of $R \& D$ investment decreases with sales volatility when the firm is more credit constrained; (b) this level decreases more in downturns for more credit-constrained firms.

\section{From R\&D to productivity growth}

In this subsection we investigate the interacted effect of PI and sales shocks on firm average productivity growth. The prediction is that the interacted effect should be negative, with growth in more credit constrained firms responding more positively to a positive sales shock.

[Table 10 about here]

Results in Table 10 are in line with these predictions. First, the effect of adverse shocks on average productivity growth for credit constrained firms is negative: the variable shock in this table is a dummy equal to 1 when the firm has experienced both, an adverse shock and a payment incident in year $t-1$; The table shows an estimated coefficient of average productivity growth on this variable which is negative and significant. When we control for sectoral R\&D intensity (captured by the mean of the share of $R \& D$ investment over total investment, computed by sector), this coefficient is no longer significant, whereas the interaction term remains negative and significant. This suggests that the negative effect of adverse shocks on productivity growth in credit constrained firms, is related to the impact of those shocks on long-term R\&D investment.

[Table 11 about here] 
Additional evidence on the role of credit constraints in the relationship between business cycles and productivity growth is presented in table 11, which presents cross-section estimations of the correlation between the volatility of growth and average TFP growth over the period 19942004. All estimations include controls for firm size and sector dummies. The impact of growth volatility alone is found to be insignificant (column (a)), but turns negative in more financially dependent industries (column (b)). In the last four columns we present separate estimations for high (above median) and low (below median) R\&D intensity sectors. Consistent with our theoretical model, the negative impact of volatility on growth in more financially dependent sectors appears only in R\&D intensive industries, suggesting that credit constraints magnify the negative impact of volatility on growth at least partly through their effects on R\&D investment.

\section{Policy implications}

An important next step in this research program will be to study the effect of macro-policy - both monetary and budgetary policies - on firms' R\&D behavior over the business cycle. In particular, our regression results in Tables 6, 10 and 11 suggest that more countercyclical macroeconomic policies (e.g with higher fiscal deficits or lower interest rates in downturns) should enhance R\&D investments and productivity growth in firms that are more credit constrained and more dependent upon external finance. However, a systematic investigation of the effects of macroeconomic policies on firms' investment behavior is left for future research. 


\section{References}

Aghion, P. and Saint-Paul, G. (1998), "On the Virtue of Bad Times: An Analysis of the Interaction between Productivity Growth and Economic Fluctuations", Macroeconomic Dynamics, vol. 2 n 3 : pp. 322-44.

Aghion, P., Angeletos, G.-M., Banerjee, A. and Manova, K. (2005), "Volatility and Growth: Credit Constraints and Productivity-Enhancing Investment", NBER Working Papers 11349 .

Barlevy, G. (2004), "The Costs of Business Cycles under Endogenous Growth", American Economic Review, vol. 94 n 4: pp. 964-990.

Barlevy, G. (2007), "On the Cyclicality of Research and Development", American Economic Review, vol. forthcoming.

BEAN, C. R. (1990), "Endogenous growth and the procyclical behaviour of productivity", European Economic Review, vol. 34 n 2-3: pp. 355-363.

Bloom, N. (2007), "Uncertainty and the Dynamics of R\&D”, NBER Working Papers 12841.

Caballero, R. and Hammour, M. (1994), "The Cleansing Effect of Recessions", American Economic Review, vol. 84 n n: $^{\text {pp. } 1350-68 .}$

Comin, D. and Gertler, M. (2006), "Medium-Term Business Cycles", American Economic Review, vol. $96 \mathrm{n}^{\mathrm{o}}$ 3: pp. 523-51.

Francois, P. and Lloyd-Ellis, H. (2003), "Animal Spririts through Creative Destruction", American Economic Review, vol. 93 n 3 : pp. 530-50. 
Gali, J. and Hammour, J. (1992), "Long Run Effects of Business Cycles", Columbia working paper 92-26.

Griliches, Z. (1990), "Patent Statistics as Economic Indicators: a Survey", Journal of Economic Literature, vol. 28 n 4: pp. 1661-1707.

HALl, B. H. (1993), "The Stock Market's Valuation of R\&D Investment during the 1980's", American Economic Review, vol. 83 no 2: pp. 259-64.

HALl, R. (1991), "Labor Demand, Labor Supply, and Employment Volatility", NBER Macroeconomics Annual.

Mulkay, B., Hall, B. H. and Mairesse, J. (2001), "Firm Level Investment and R\&D in France and the United States: A Comparison", NBER Working Papers 8048.

Rajan, R. G. and Zingales, L. (1998), "Financial Dependence and Growth", American Economic Review, vol. 88 n 3: pp. 559-86.

Ramey, G. and Ramey, V. A. (1995), "Cross-Country Evidence on the Link between Volatility and Growth", American Economic Review, vol. 85 n n $^{\circ}$ : pp. 1138-51.

Schumpeter, J. A. (1942), Capitalism, Socialism, and Democracy, New York: Harper and Brothers.(Harper Colophon edition, 1976.). 


\section{Tables}

Table 1: Descriptive Statistics, whole sample

\begin{tabular}{l|cccccccc} 
Variable & No Obs. No. Firms Mean & S.D & Q1 & Median & Q3 \\
& & & & & & & \\
\hline & & & & & & & \\
Whole Sample & & & & & & & \\
No Employees & 73,237 & 12,966 & 94.70 & 288.03 & 16 & 32 & 68 \\
Sales (1) & 73,237 & 12,966 & 21141 & $1.9 \mathrm{e}+05$ & 2098 & 4417 & 11126 \\
Variation in Sales & 73,237 & 12,966 & 0.04 & 0.19 & -0.05 & 0.04 & 0.13 \\
Payment Incidents (PI) & 73,237 & 12,966 & 0.07 & 0.26 & 0.00 & 0.00 & 0.00 \\
R\&D Share (2) & 73,237 & 12,966 & 0.05 & 0.14 & 0.00 & 0.00 & 0.00 \\
& & & & & & & \\
\hline & & & & & & & \\
Credit Constrained Firms (4) & & & & & & & \\
& & & & & & & & \\
No Employees & 26,864 & 4,646 & 110.86 & 331.63 & 17.00 & 34.00 & 72.00 \\
Sales (1) & 26,864 & 4,646 & 24512 & $1.9 \mathrm{e}+05$ & 1919 & 4113 & 10549 \\
Variation in Sales & 26,864 & 4,646 & 0.04 & 0.19 & -0.05 & 0.04 & 0.13 \\
Payment Incidents & 26,864 & 4,646 & 0.20 & 0.40 & 0.00 & 0.00 & 0.00 \\
R\&D Share (4) & 26,864 & 4,646 & 0.04 & 0.15 & 0.00 & 0.00 & 0.00 \\
& & & & & & & \\
\hline
\end{tabular}

Non Credit Constrained Firms (5)

\begin{tabular}{l|ccccccc} 
No employees & 46,373 & 8,320 & 85.33 & 258.98 & 16.00 & 31.00 & 66.00 \\
Sales (1) & 46,373 & 8,320 & 19189 & $1.8 \mathrm{e}+05$ & 2210 & 4589 & 11454 \\
Variation in Sales & 46,373 & 8,320 & 0.05 & 0.19 & -0.04 & 0.04 & 0.13 \\
R\&D Share (4) & 46,373 & 8,320 & 0.05 & 0.14 & 0.00 & 0.00 & 0.00 \\
& & & & & & & \\
\hline First Stage & & & & & & & \\
& & & & & & & \\
No employees & 51,656 & 11,392 & 98.30 & 292.25 & 17.00 & 34.00 & 72.00 \\
New Bank Loans / VA & 54,253 & 11,392 & 0.03 & 1.37 & 0.00 & 0.00 & 0.01 \\
Long Term / Total Loans & 54,572 & 11,367 & 0.39 & 0.38 & 0.00 & 0.27 & 0.77 \\
Collateral (1) & 51,656 & 11,392 & 15784 & $1.8 \mathrm{e}+05$ & 688 & 1716 & 4939 \\
Bank Debt / Total Financing & 51,651 & 11,390 & 0.22 & 0.20 & 0.05 & 0.17 & 0.33
\end{tabular}

Note: (1) : Thousands of euros; (2) R\&D share : R\&D investment / (Physical Investment + R\&D Investment); (3) Capital Stock Growth Rate : $I_{t} / K_{t-1} ;(4)$ : At least 1 payment incident during the period; (5) no payment incident during the period; Positive R\&D investment rate for $24 \%$ of the total number of observations. Source: Authors' computations from Fiben / Centrale des Bilans, Banque de France. 


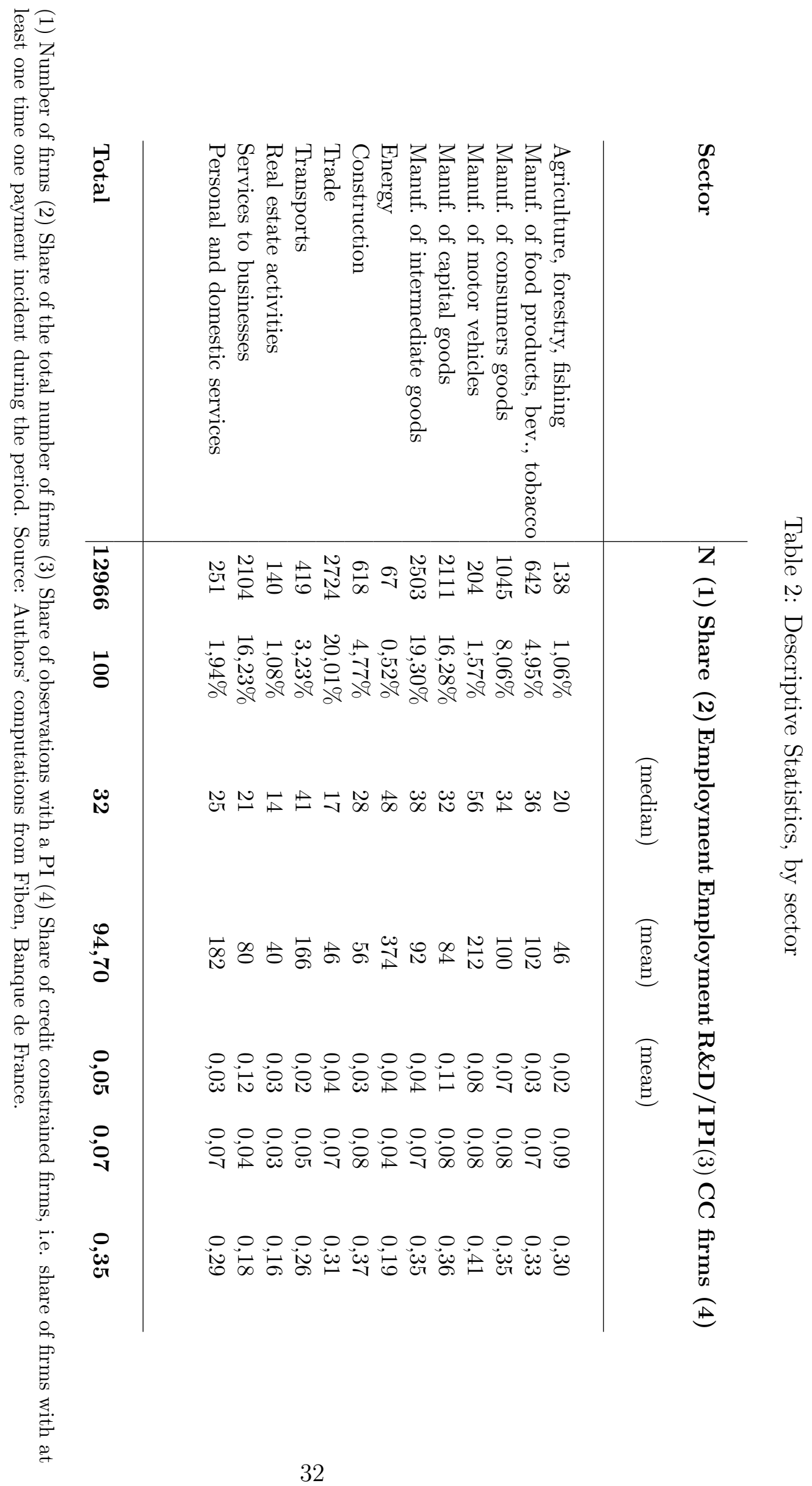


Table 3: Effect of R\&D on TFP Growth

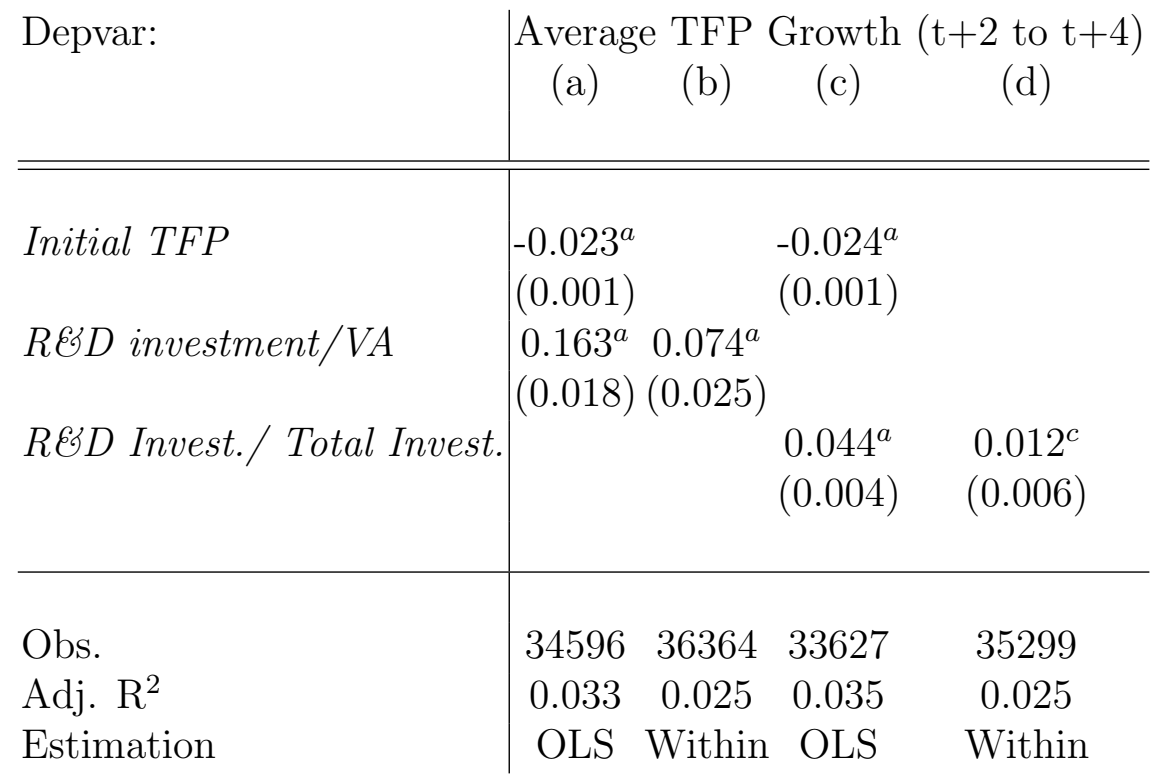

Note: Panel, within estimation. Robust standard errors into parentheses. Significance levels: ${ }^{c} 10 \%,{ }^{b} 5 \%,{ }^{a} 1 \%$. All estimations include year dummies. Intercept not reported. 


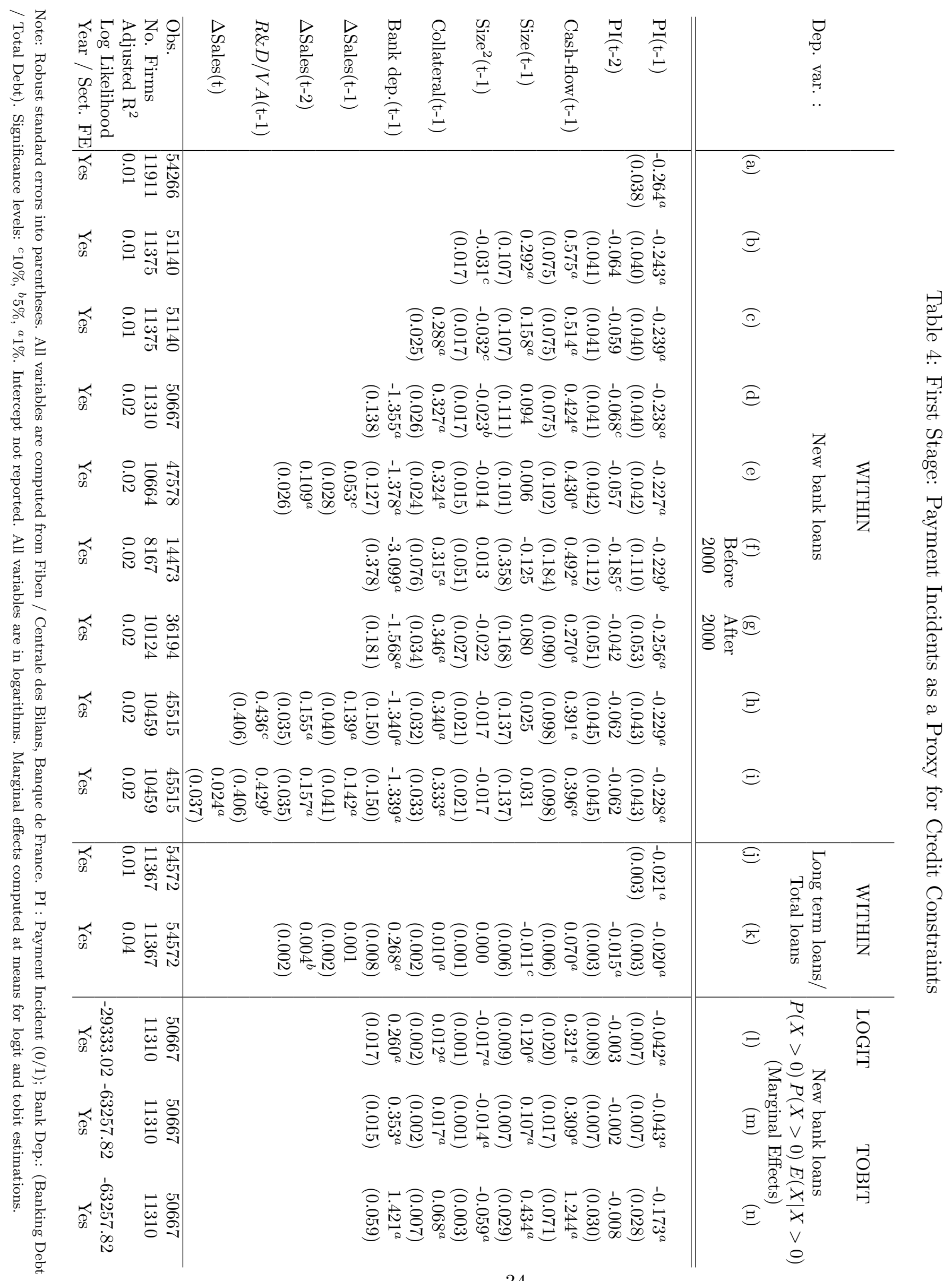


Table 5: Credit constraints and the cyclical composition of investment (1)

Depvar: RED investment / Total Investment

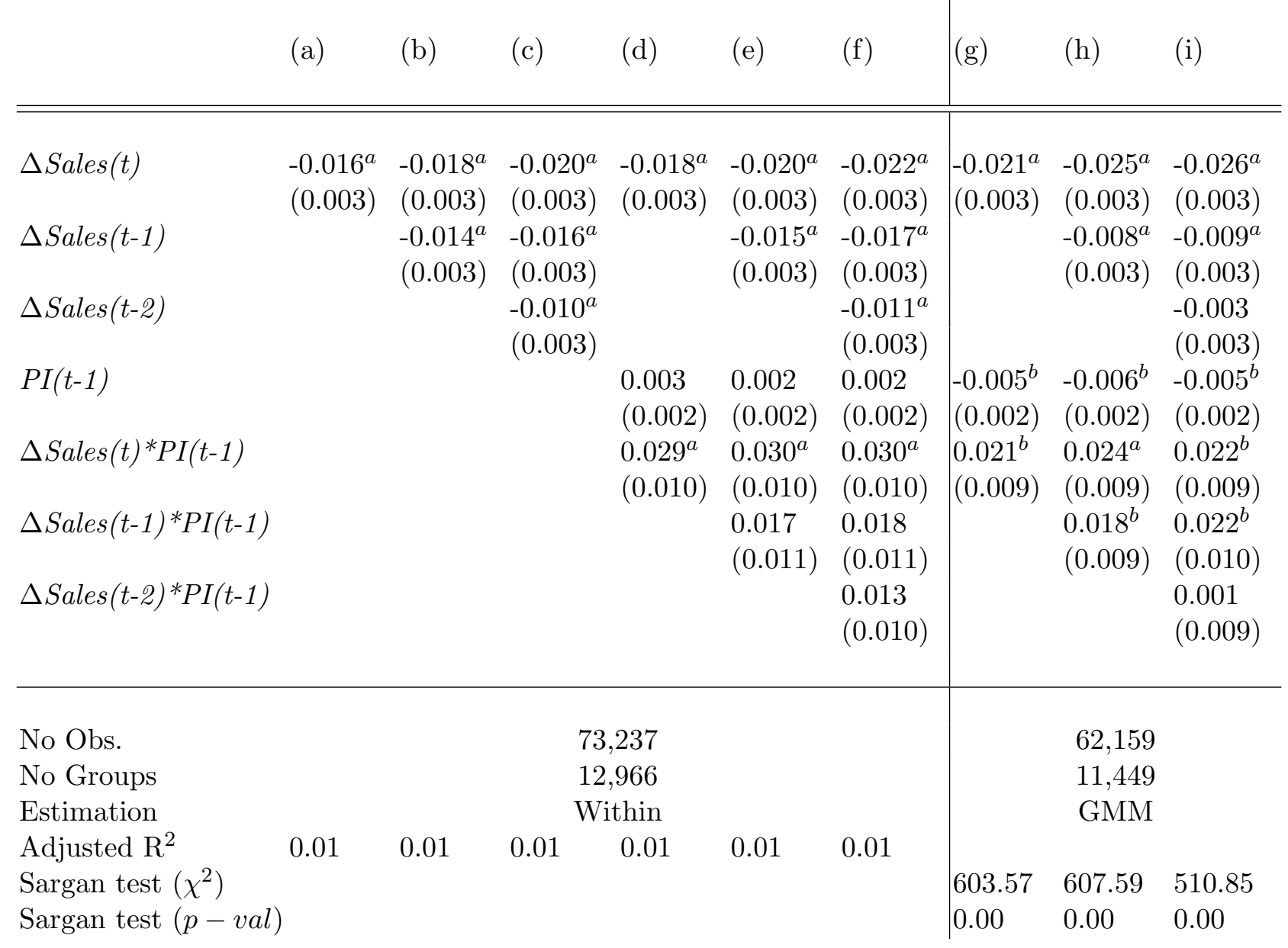

Note: Panel, within estimation. Robust standard errors into parentheses. Significance levels: ${ }^{c} 10 \%,{ }^{b} 5 \%,{ }^{a} 1 \%$. All estimations include year dummies. Intercept not reported. 
Table 6: Second stage regressions with financial dependence and collateral Depvar: R\&D investment / Total Investment

Fin. Dependence

Collateral

Low High How High
(a)
(b)
(c)
(d)

\begin{tabular}{|c|c|c|c|c|}
\hline$\Delta \operatorname{Sales}(t)$ & $\begin{array}{l}-0.021^{a} \\
(0.005)\end{array}$ & $\begin{array}{r}-0.038^{a} \\
(0.006)\end{array}$ & $\begin{array}{l}-0.027^{a} \\
(0.005)\end{array}$ & $\begin{array}{r}-0.012^{a} \\
(0.004)\end{array}$ \\
\hline$\Delta$ Sales $(t-1)$ & $\begin{array}{l}-0.012^{b} \\
(0.005)\end{array}$ & $\begin{array}{l}-0.032^{a} \\
(0.006)\end{array}$ & $\begin{array}{l}-0.019^{a} \\
(0.005)\end{array}$ & $\begin{array}{l}-0.015^{a} \\
(0.004)\end{array}$ \\
\hline$\Delta$ Sales(t-2) & $\begin{array}{l}-0.013^{a} \\
(0.005)\end{array}$ & $\begin{array}{l}-0.027^{a} \\
(0.006)\end{array}$ & $\begin{array}{l}-0.010^{b} \\
(0.004)\end{array}$ & $\begin{array}{l}-0.013^{a} \\
(0.004)\end{array}$ \\
\hline$P I(t-1)$ & $\begin{array}{l}0.003 \\
(0.004)\end{array}$ & $\begin{array}{l}0.002 \\
(0.005)\end{array}$ & $\begin{array}{l}0.001 \\
(0.004)\end{array}$ & $\begin{array}{l}0.002 \\
(0.003)\end{array}$ \\
\hline$\Delta \operatorname{Sales}(t) * P I(t-1)$ & $\begin{array}{l}0.026 \\
(0.020)\end{array}$ & $\begin{array}{l}0.049^{b} \\
(0.020)\end{array}$ & $\begin{array}{l}0.043^{a} \\
(0.016)\end{array}$ & $\begin{array}{l}0.010 \\
(0.012)\end{array}$ \\
\hline$\Delta$ Sales $(t-1) * P I(t-1)$ & $\begin{array}{l}-0.001 \\
(0.019)\end{array}$ & $\begin{array}{l}0.011 \\
(0.023)\end{array}$ & $\begin{array}{l}0.029^{c} \\
(0.017)\end{array}$ & $\begin{array}{l}0.005 \\
(0.014)\end{array}$ \\
\hline$\Delta$ Sales $(t-2) * P I(t-1)$ & $\begin{array}{l}0.000 \\
(0.018)\end{array}$ & $\begin{array}{l}0.049^{b} \\
(0.021)\end{array}$ & $\begin{array}{l}0.012 \\
(0.014)\end{array}$ & $\begin{array}{l}0.017 \\
(0.012)\end{array}$ \\
\hline No Observations & 20028 & 18457 & 36639 & 36598 \\
\hline No Firms & 3403 & 3221 & 8212 & 6589 \\
\hline Estimation & \multicolumn{4}{|c|}{ Within } \\
\hline Adjusted $\mathrm{R}^{2}$ & 0.01 & 0.01 & 0.01 & 0.01 \\
\hline
\end{tabular}


Table 7: Credit constraints and the cyclical composition of investment, asymmetry, Within estimations (1)

\begin{tabular}{|c|c|c|c|c|c|c|c|c|}
\hline \multirow{2}{*}{ Depvar: } & \multicolumn{8}{|c|}{ RESD investment / Total Investment } \\
\hline & \multicolumn{4}{|c|}{ Decomposition by firm (1) } & \multicolumn{4}{|c|}{ Decomposition by Sector (2) } \\
\hline & (a) & (b) & (c) & (d) & (e) & (f) & $(\mathrm{g})$ & (h) \\
\hline High $\Delta$ Sales $(t)$ & $-0.020^{a}$ & $-0.023^{a}$ & $-0.021^{a}$ & $-0.023^{a}$ & $-0.017^{a}$ & $-0.019^{a}$ & $-0.018^{a}$ & $-0.020^{a}$ \\
\hline Low $\Delta$ Sales $(t)$ & $\begin{array}{l}(0.004) \\
-0.008\end{array}$ & $\begin{array}{l}(0.004) \\
-0.011^{b}\end{array}$ & $\begin{array}{l}(0.004) \\
-0.014^{b}\end{array}$ & $\begin{array}{l}(0.004) \\
-0.016^{a}\end{array}$ & $\begin{array}{l}(0.004) \\
-0.010^{c}\end{array}$ & $\begin{array}{l}(0.004) \\
-0.013^{b}\end{array}$ & $\begin{array}{l}(0.004) \\
-0.016^{a}\end{array}$ & $\begin{array}{l}(0.004) \\
-0.019^{a}\end{array}$ \\
\hline & $(0.005)$ & $(0.005)$ & $(0.006)$ & $(0.006)$ & $(0.006)$ & $(0.006)$ & $(0.006)$ & $(0.006)$ \\
\hline High $\Delta$ Sales $(t-1)$ & & $-0.015^{a}$ & & $-0.017^{a}$ & & $-0.013^{a}$ & & $-0.015^{a}$ \\
\hline Low $\Delta$ Sales $(t-1)$ & & $\begin{array}{c}(0.004) \\
-0.012^{b} \\
(0.066)\end{array}$ & & $\begin{array}{c}(0.004) \\
-0.012^{b} \\
(0.006\end{array}$ & & $\begin{array}{c}(0.004) \\
-0.013^{b} \\
(0006)\end{array}$ & & $\begin{array}{c}(0.004) \\
-0.013^{b} \\
(0.006\end{array}$ \\
\hline$P I(t-1)$ & & & $\begin{array}{l}0.003 \\
(0.003)\end{array}$ & $\begin{array}{l}0.003 \\
(0.003)\end{array}$ & & & $\begin{array}{l}0.003 \\
(0.002)\end{array}$ & $\begin{array}{l}0.003 \\
(0.003)\end{array}$ \\
\hline High $\Delta$ Sales $(t) * P I(t-1)$ & & & $\begin{array}{l}0.005 \\
(0.016)\end{array}$ & $\begin{array}{l}0.005 \\
(0.016)\end{array}$ & & & $\begin{array}{l}0.007 \\
(0.015)\end{array}$ & $\begin{array}{l}0.005 \\
(0.016)\end{array}$ \\
\hline Low $\Delta$ Sales $(t) * P I(t-1)$ & & & $\begin{array}{l}0.054^{a} \\
(0.017)\end{array}$ & $\begin{array}{l}0.055^{a} \\
(0.017)\end{array}$ & & & $\begin{array}{l}0.056^{a} \\
(0.017)\end{array}$ & $\begin{array}{l}0.058^{a} \\
(0.017)\end{array}$ \\
\hline High $\Delta$ Sales $(t-1) * P I(t-1)$ & & & & $\begin{array}{l}0.024 \\
(0.016)\end{array}$ & & & & $\begin{array}{l}0.024 \\
(0.016)\end{array}$ \\
\hline Low $\Delta$ Sales $(t-1)^{*} P I(t-1)$ & & & & $\begin{array}{l}0.005 \\
(0.021)\end{array}$ & & & & $\begin{array}{l}0.001 \\
(0.021)\end{array}$ \\
\hline Adjusted $\mathrm{R}^{2}$ & 0.01 & 0.01 & 0.01 & 0.01 & 0.01 & 0.01 & 0.01 & 0.01 \\
\hline No Obs. & & 73 & 237 & & & & 237 & \\
\hline No Firms & & 12, & 966 & & & & 966 & \\
\hline Estimation & & WIT & CHIN & & & WIT & THIN & \\
\hline
\end{tabular}

Note: (1) Decomposition by firm: above (high) and below (low) firm's mean sales' variation; (2) Decomposition by sector: firm above the third quartile of its sector's sales variation (high) or below the first quartile (low). Panel, within estimations. Robust standard errors into parentheses. Significance levels: ${ }^{c} 10 \%,{ }^{b} 5 \%,{ }^{a} 1 \%$. All estimations include year dummies. Intercept not reported. 
Table 8: Asymmetry, with initial state

Dep. var. RED investment/ Total Investment

Est.

(a)

(b)

(c)

(d)

Initital State:

High Low

High

Low

\begin{tabular}{lllll}
\hline \hline & & & & \\
High $\Delta$ Sales $(t)$ & -0.002 & $-0.025^{a}$ & $-0.013^{a}$ & $-0.029^{a}$ \\
& $(0.006)$ & $(0.005)$ & $(0.010)$ & $(0.010)$ \\
Low $\Delta$ Sales $(t)$ & $-0.018^{a}$ & $-0.027^{a}$ & $-0.030^{a}$ & $-0.008^{a}$ \\
& $(0.006)$ & $(0.009)$ & $(0.005)$ & $(0.005)$ \\
PI $(t-1)$ & 0.004 & 0.003 & 0.003 & -0.004 \\
& $(0.003)$ & $(0.003)$ & $(0.007)$ & $(0.007)$ \\
High $\Delta$ Sales $(t)^{*} P I(t-1)$ & 0.025 & 0.007 & -0.013 & -0.008 \\
& $(0.024)$ & $(0.018)$ & $(0.017)$ & $(0.017)$ \\
Low $\Delta$ Sales $(t)^{*} P I(t-1)$ & $0.042^{b}$ & $0.060^{b}$ & $0.091^{a}$ & $0.028^{b}$ \\
& $(0.020)$ & $(0.025)$ & $(0.020)$ & $(0.021)$ \\
& & & & \\
\hline \multirow{5}{*}{ No. Obs. } & 34,360 & 38,877 & 32,656 & 36,863 \\
No. Firms & 11,563 & 12,597 & 11,099 & 12,074 \\
Adj. R ${ }^{2}$ & 0.002 & 0.004 & & \\
Estimation & \multicolumn{3}{c}{ Within }
\end{tabular}

Note: High resp. low) state: sales per employee above (resp. below) firms' median. Standard errors into parentheses. Significance levels: ${ }^{c} 10 \%,{ }^{b} 5 \%,{ }^{a} 1 \%$. All estimations include year dummies. Intercept and lag of the dependent variable not reported for GMM estimates. All variables are in logarithms. 
Table 9: On the Level of Physical Investment

Dep. var.

$$
\frac{I_{t}}{K_{t-1}}
$$
(a)
(b)
(c)

$$
\begin{array}{llll}
\text { Inv }(t-1) / K(t-2) & 0.058^{a} & 0.058^{a} & 0.058^{a} \\
& (0.008) & (0.008) & (0.008) \\
\Delta \text { Sales }(t) & 0.127^{a} & 0.127^{a} & 0.126^{a} \\
& (0.006) & (0.006) & (0.007) \\
\Delta \text { Sales }(t-1) & 0.095^{a} & 0.095^{a} & 0.095^{a} \\
& (0.006) & (0.006) & (0.006) \\
\text { PI }(t-1) & & -0.013^{a} & -0.012^{a} \\
& & (0.004) & (0.004) \\
\Delta \text { Sales }(t){ }^{*} \text { PI }(t-1) & & & 0.007 \\
& & (0.021) \\
\Delta \text { Sales }(t-1) * \text { PI }(t-1) & & -0.008 \\
& & & (0.023)
\end{array}
$$

\begin{tabular}{llll} 
Adjusted R & & & \\
No Obs. & 0.08 & 0.08 & 0.08 \\
No Firms & 72,609 & 72,609 & 72,609 \\
Estimation & 12,877 & 12,877 & 12,877 \\
& \multicolumn{3}{c}{ Within }
\end{tabular}

Note: Robust standard errors into parentheses. Significance levels: ${ }^{c} 10 \%,{ }^{b} 5 \%,{ }^{a} 1 \%$. All estimations include year and sector dummies. Intercept not reported. 
Table 10: Productivity, R\&D and Credit Constraints

Dep. var.:

MEAN TFP Growth $(t+2)$ to $(t+5)$
(a)
(b)
(c)
(d)

\begin{tabular}{lllll}
\hline \hline & & & & \\
Initial TFP & $-0.031^{a}$ & $-0.031^{a}$ & & \\
Shock & $(0.001)$ & $(0.001)$ & & \\
& $-0.063^{a}$ & -0.017 & $-0.037^{c}$ & 0.001 \\
Sect. REDD Intensity & $(0.019)$ & $(0.026)$ & $(0.020)$ & $(0.027)$ \\
& $1.104^{a}$ & $1.095^{a}$ & & \\
Shock*Sect RED Intensity & $(0.041)$ & $(0.042)$ & & $-3.284^{b}$ \\
& & $-3.936^{a}$ & & $(1.575)$ \\
& & $(1.487)$ & & \\
No obs. & 33,973 & 33,973 & 33,973 & 33,973 \\
$\mathrm{R}^{2}$ & 0.05 & 0.06 & 0.05 & 0.05 \\
Est. & \multicolumn{5}{c}{ OLS } & Fixed Effects / Within
\end{tabular}

Note: Robust standard errors into parentheses. Significance levels: ${ }^{c} 10 \%,{ }^{b} 5 \%,{ }^{a} 1 \%$. All estimations include year dummies. Shock equals 1 if the firm is credit constraint and has a negative shock in t, 0 otherwise. R\&D intensity : industry mean of R\&D Investment / Total Investment. 
Table 11: Volatility, Growth and Credit Constraints

\begin{tabular}{|c|c|c|c|c|c|c|}
\hline $\begin{array}{l}\text { Est. : } \\
\text { Dep. Var }\end{array}$ & ${ }^{\text {(a) }} \mathrm{TFF}$ & $\begin{array}{l}\text { (b) } \\
\text { Growth }\end{array}$ & $\mid \begin{array}{l}(\mathrm{c}) \\
\mathrm{TFI} \\
\text { High R }\end{array}$ & $\begin{array}{l}\text { (d) } \\
\text { Growth } \\
\text { intensity }\end{array}$ & ${ }_{\text {Low } \mathrm{R}}^{\mathrm{T}} \mathrm{TF}$ & $\begin{array}{l}\text { (f) } \\
\text { Growth } \\
\text { intensity }\end{array}$ \\
\hline Initial TFP & $\begin{array}{l}-0.021^{a} \\
(0.003)\end{array}$ & $\begin{array}{l}-0.020^{a} \\
(0.004)\end{array}$ & $\begin{array}{l}-0.021^{a} \\
(0.005)\end{array}$ & $\begin{array}{r}-0.020^{a} \\
(0.005)\end{array}$ & $\begin{array}{l}-0.022^{a} \\
(0.005)\end{array}$ & $\begin{array}{l}-0.022^{a} \\
(0.005)\end{array}$ \\
\hline $\begin{array}{l}\text { Growth Volatility } \\
\text { Growth volatility*Fin. Dep }\end{array}$ & $\begin{array}{l}0.003 \\
(0.022)\end{array}$ & $\begin{array}{l}-0.037 \\
(0.028) \\
-0.033^{c} \\
(0.018)\end{array}$ & $\begin{array}{l}-0.012 \\
(0.035)\end{array}$ & $\begin{array}{l}-0.074^{c} \\
(0.039) \\
-0.066^{c} \\
(0.037)\end{array}$ & $\begin{array}{l}0.012 \\
(0.026)\end{array}$ & $\begin{array}{l}-0.015 \\
(0.038) \\
-0.018 \\
(0.021)\end{array}$ \\
\hline $\begin{array}{l}\text { No. Observations } \\
\mathrm{R}^{2}\end{array}$ & $\begin{array}{l}4459 \\
0.141\end{array}$ & $\begin{array}{l}4459 \\
0.146\end{array}$ & $\begin{array}{l}2249 \\
0.152\end{array}$ & $\begin{array}{l}2249 \\
0.164\end{array}$ & $\begin{array}{l}2310 \\
0.089\end{array}$ & $\begin{array}{l}2310 \\
0.090\end{array}$ \\
\hline
\end{tabular}

Note: Robust standard errors into parentheses. Significance levels: ${ }^{c} 10 \%,{ }^{b} 5 \%,{ }^{a} 1 \%$. OLS estimations, over the period 1994-2004; each estimation includes sector and size dummies. Rajan and Zingales (1998) data for sectoral financial dependence. R\&D intensity : industry mean of R\&D Investment / Total Investment. Large (resp. low) R\&D intensity: above (resp. below) median of R\&D intensity.

Table 12: Variables Description

\begin{tabular}{|c|c|c|}
\hline Variable & Description & Source \\
\hline New bank loans & Total amount of new bank loans & Centrale des Bilans, Banque de France (BdF) \\
\hline Payment Incident & $\begin{array}{l}1 \text { when the firm experienced at least } \\
\text { one payment incident, } 0 \text { otherwise }\end{array}$ & Observatoire des entreprises, $\mathrm{BdF}$ \\
\hline$\Delta$ Sales & $\log ($ sales $)-\log ($ sales $(\mathrm{t}-1))$ & Fiben, BdF \\
\hline Size & Number of Employees & Fiben, BdF \\
\hline Collateral & Sum of fixed and tangible assets & Fiben, BdF \\
\hline Banking Debt & $\begin{array}{c}\text { Banking debt } / \\
(\text { Own Financing }+ \text { Market Financing }+ \text { Financial Debt })\end{array}$ & Fiben, BdF \\
\hline R\&D Share & R\&D Investment / (Physical + R\&D Investment) & Fiben, BdF \\
\hline
\end{tabular}


Table 13: Correlations

\begin{tabular}{|c|c|c|c|c|c|}
\hline Variable & Var. Sales & PI & Inv. Rate (1) & $\begin{array}{l}\text { R\&D Inv. } \\
(2)\end{array}$ & Rate R\&D Share (3) \\
\hline Variation in Sales & 1.0000 & & & & \\
\hline Payment Incidents & -0.0416 & 1.0000 & & & \\
\hline Investment Rate (1) & 0.349 & -0.0068 & 1.0000 & & \\
\hline R\&D Investment Rate (2) & -0.006 & 0.0331 & 0.2137 & 1.0000 & \\
\hline R\&D Share (3) & -0.0041 & 0.0363 & 0.0611 & 0.7697 & 1.0000 \\
\hline
\end{tabular}

Note: (1) Capital Stock Growth Rate : $I_{t} / K_{t-1} ;(2)$ : R\&D Investment / Value Added; (3) R\&D share : R\&D investment / (Physical Investment + R\&D Investment); ; Source: Authors' computations from Fiben / Centrale des Bilans, Banque de France. 